\title{
IMPLEMENTASI RANCANGAN APLIKASI PROGRAM PEMBELAJARAN IPA MATERI SISTEM PERNAPASAN UNTUK SDLB BAGIAN B TUNARUNGU BERBASIS MULTIMEDIA
}

\author{
Diana Effendi \\ Fakultas Teknik dan Informatika, Program Studi Manajemen Informatika \\ Universitas Komputer Indonesia \\ Email: diana.effendi@email.unikom.ac.id \\ Bella Hardiyana \\ Fakultas Teknik dan Informatika, Program Studi Sistem Informasi \\ Universitas Komputer Indonesia \\ Email: bella.hardiyana@email.unikom.ac.id \\ Iyan Gustiana \\ Fakultas Teknik dan Informatika, Program Studi Sistem Informasi \\ Universitas Komputer Indonesia \\ Email: iyan.gustiana@email.unikom.ac.id
}

\begin{abstract}
ABSTRAK
Penelitian ini merupakan lanjutan dari penelitian sebelumnya yaitu perancangan program aplikasi pembelajaran IPA materi sistem pernapasan berbasis multimedia untuk siswa SDLB Bagian B Tunarungu menggunakan Object Oriented. Bagaimana implementasi rancangan program yang sudah dibuat kedalam program aplikasi dibahas dalam penelitian ini. Implementasi tiap rancangan halaman aplikasi kedalam bentuk kode program menggunakan software Adobe Flash CS 6 Profesional Edition. Dengan software tersebut, tiap halaman aplikasi dibangun dengan konsep multimedia yang menggabungkan audio, visual, animasi, dan dilengkapi dengan bahasa isyarat. Sehingga materi pembelajaran sistem pernapasan manusia dan hewan dapat dijelaskan secara terperinci tahapan tiap proses yang terjadi di sistem tersebut. Hasil penelitian ini berupa program aplikasi pernapasan pada manusia dan hewan berbasis multimedia. Hasil penelitian ini berupa program aplikasi pernapasan pada manusia dan hewan berbasis multimedia.
\end{abstract}

Kata kunci: pembelajaran IPA, sistem pernapasan manusia dan hewan, multimedia.

\begin{abstract}
This study is a continuation of previous research, namely the design of application program learning IPA material respiratory system-based multimedia for Deaf students SDLB part B using Object Oriented. How the implementation of the draft programme that was made into the applications discussed in this study. The implementation of each application page design into form code using the software Adobe Flash CS 6 Professional Edition. With the software, each page of the application is built with multimedia which combine visual, audio, animation, and comes with sign language. Learning material so that the respiratory system of humans and animals can be explained in detail each stage of the process that occurs in the system. Resukt of this research is application program of repositorysystem of humans and animal based multimedia.
\end{abstract}

Keywords: science lesson, respiratory system in humans and animals, multimedia.

\section{PENDAHULUAN}

Pendidikan berbasis komputer (Computer-Based Education) menggunakan softwarependidikan yang diakses melalui komputer, dimana peserta didik dapat berinteraksi dengan program tersebut. Penerapan Computer Based Education sepert ini dikenal dengan istilah Computer-Assisted Instruction (CAI). Materi pelajaran dapat disajikan program $C A I$ melalui berbagai metode seperti: drill and practice, tutorial, simulasi, games, problem-solving, dan lain sebagainya (Heinich et al, 1993) [1].Dalam CAI aplikasi komputer sebagai bagian integral dalam sistem pembelajaran terhadap proses belajar dan mengajar yang bertujuan membantu peserta didik dalam belajarnya bisa melalui pola interaksi dua arah melalui terminal komputer mau pun multi arah yang diperluas melalui jaringan komputer (baik lokal mau pun global) dan juga diperluas fungsinya melalui interface (antar muka) multimedia (Emithu, 2010) [1,2].CAI merupakan penerapan pemanfaatan komputer untuk penyampaian materi pembelajaran melalui multimedia. 
Multimedia berasal dari dua kata, yaitu multi dan media. Multi berarti banyak dan media biasa diartikan alat untuk menyampaikan atau membuat sesuatu, perantaraan, alat pengantar, suatu bentuk komunikasi [3,4]. Menurut Effendi, 2014 keuntungan pembelajaran multimedia yaitu

"The advantages of multimedia is interesting the senses and interest, as a combination of sight, sound and motion [5]".

Multimedia yang dimaksud di sini adalah suatu teknologi yang menggabungkan berbagai sumber media seperti teks, grafik, suara, animasi, video dan sebagainya, yang disampaikan dan dikontrol oleh sistem komputer secara interaktif. Menurut Effendi,2014,menyatakan lebih lanjut keuntungan pembelajaran menggunakan multimedia yaitu :

"The learning process is fun, creative, and not boring the choice of the teacher. If this learning situation is not created, at least multimedia to make learning more effective. Excess other multimedia such as no need to print a hard copy and can be created or edited at the time of teaching become easier for teachers in the delivery of the material. A wide variety of visual display or audio even begin to try to move as animation, video clips, audio recordings, blend colors made to get a teaching aid as well as possible[5]”.

Jadi dapat disimpulkan bahwa tujuan produk multimedia ditampilkan melalui komputer adalah agar user bisa melihat, mendengar, saling berinteraksi, dan mengontrol tampilan media tersebut. Produk multimedia haruslah memiliki hubungan yang membenarkan user untuk bergerak dari satu antarmuka ke antarmuka yang lain dan pada saat tertentu dibantu oleh struktur dan ruang tersendiri. Tanpa sifat tersebut, produk multimedia tersebut tidak lebih menyerupai sebuah buku. Sedangkan format sajian multimedia pembelajaran dapat dikategorikan ke dalam lima kelompok sebagai berikut: Tutorial, Drill dan Practise, Simulasi, Percobaan atau Eksperimen, Permainan[6,7].

Aplikasi program pembelajaran materi sistem pernapasan manusia dan hewan ini, dibuat dengan memperhatikan kaidah-kaidah program multimedia yang menggabungkan audio, video dan animasi yang disesuaikan dengan kebutuhan Anak Berkebutuhan Khusus (ABK) tunarungu dan guru pengajar [4].Rancangan yang dibuat sebelumnya memfokuskan pada visual animasi, dikarenakan ABK kesulitan dalam menggunakan indera pendengaran yang merupakan organ vital dalam proses belajar mengajar [4]. Hal ini dilakukan mengingat salah satu karakteristik CAlyaitu relevan dengan ragam karakteristik peserta didik dan mengoptimalkan interaksi belajar peserta didik dengan materi ajar [7].Objek penelitian ini di SDLB Bagian B Cicendo Bandung kelas V. Dalam penelitian ini dibahasbagaimana mengimplementasikan rancangan sistem maupun rancangan interface aplikasi program pembelajaran materi pernapasan dan hewan yang sudah dibuat pada penelitian sebelumnya kedalam software Adobe Flash CS 6 Profesional Edition.

\section{METODE PENELITIAN}

Metoda Penelitian yang digunakan adalah Development Research[4]. Penelitian Pengembangan juga didefinisikan sebagai suatu proses atau langkah-langkah untuk mengembangkan suatu produk baru atau menyempurnakan produk yang telah ada yang dapat dipertanggungjawabakan [8]. Produk yang dihasilkan dapat berupa benda atau prangkat keras (hardware) dan dapat juga berupa perangkat lunak (software). Penelitian ini menggunakan Development Researchkarena bertujuan untuk mengembangkan suatu produk berdasarkan kebutuhan dari suatu penelitian yang dilakukan sebelumnya [4]. Pengembangan yang dilakukan software animasi interaktif.

Sedangkan prosedur dalam penelitian ini ada lima tahapan yakni: (1) Menentukan konsep, (2) Desain Media , (3) Pengumpulan Bahan, (4) Proses Pembuatan (Assembly), dan (5) Uji Coba (Testing). Langkah 1 sampai dengan langkah 3 sudah dilakukan di penelitian sebelumnya.

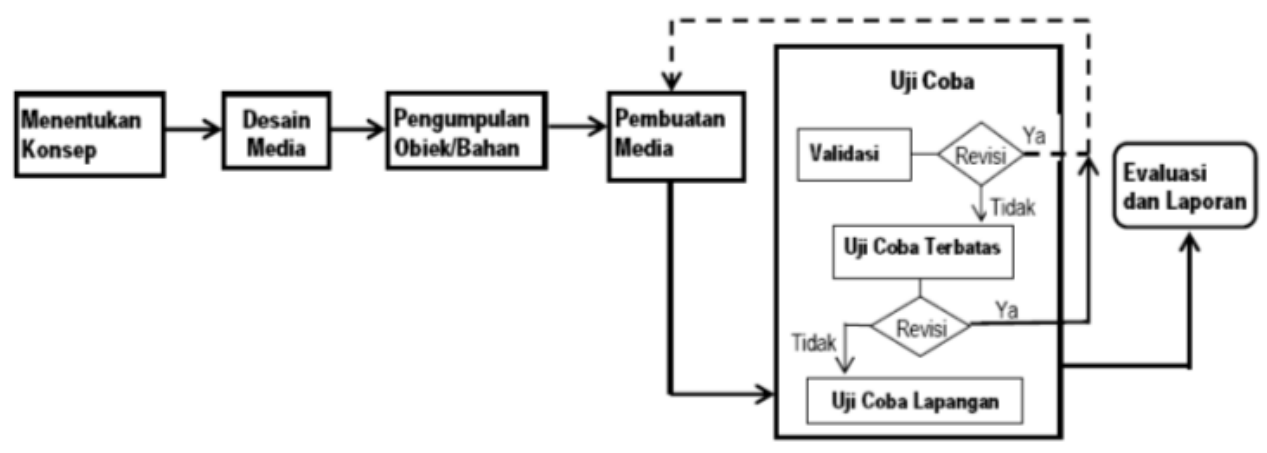

Gambar 1. Prosedur Penelitian 


\section{HASIL PENELITIAN DAN PEMBAHASAN}

Tahap implementasi merupakan kelanjutan dari kegiatan perancangan sistem dan dapat dipandang sebagai suatu usaha dalam mewujudkan sistem yang dirancang. Langkah-langkah dari proses implementasi adalah urutan dari kegiatan awal sampai kegiatan akhir yang harus dilakukan untuk mewujudkan sistem yang dirancang.

\subsection{Implementasi Perangkat Lunak}

Untuk mendukung aplikasi yang dibuat, maka diperlukan perangkat lunak (software). Kebutuhan minimum perangkat lunak yang harus terinstal pada komputer untuk menjalankan aplikasi ini adalah sebagai berikut:

a. Dari sisi pengembang

1) Sistem Operasi : Windows 864 bit

2) Software Utama: Adobe Flash CS 6 Pro

a) Target : Flash Player 11.2

b) Script (Bahasa Pemrograman) : ActionScript 2.0 (AS 2.0)

c) FPS : $24 \mathrm{fps}$

d) Resolusi : $1280 \times 720$

3) SoftwarePendukung,Pengolah Video : Camtasia Studio 8

a) Ekstensi file : .MP4

b) FPS : $17 \mathrm{fps}$

c) Resolusi : $288 \times 512$

b. Dari sisi pengguna

1) Sistem Operasi

a) Untuk Windows minimal Windows Xp SP2

b) Untuk Machintos minimal Mac OS X v10.6

c) Untuk Linux minimal Red Hat 5.6 (32 bit maupun 64 bit) atau OpenSUSE 11.3 (32 bit maupun 64 bit) atau Ubuntu 10.04 (32 bit maupun 64 bit)

2) Adobe Flash Player (Ini hanya dibutuhkan jika aplikasi ingin dibuka di Web Browser)

3) Web Browser (Ini hanya dibutuhkan jika Sistem Operasi bukan Windows)

4) PDF Reader (dibutuhkan untuk membuka file "MANUAL BOOK.pdf")

\subsection{Implementasi Perangkat Keras}

Selain perangkat lunak, juga dibutuhkan perangkat keras untuk membangun aplikasi ini. Adapun kebutuhan minimun perangkat keras untuk menjalankan aplikasi ini adalah sebagai berikut:

a. Dari sisi pengembang

1) CPU Core i5 $4200 \mathrm{CPU} 1.60 \mathrm{GHz}$

2) RAM minimal $8 \mathrm{~Gb}$

3) VGA Card $2 \mathrm{~Gb}$

4) Harddisk minimal $500 \mathrm{~Gb}$

5) Soundcard.

6) Mouse.

7) Keyboard.

8) Monitor dengan resolusi layar $1366 \times 768$

b. Dari sisi pengguna

1) $\mathrm{CPU}$ dengan prosesor minimum Intel Atom $1.6 \mathrm{GHz}$ jika menggunakan sistem operasi Windows atau Linux, atau prosesor Intel Core Duo $1.83 \mathrm{GHz}$ jika menggunakan sistem operasi Machintos dengan versi minimum sebagaimana telah disebutkan pada bab implementasi perangkat lunak.

2) RAM minimal $512 \mathrm{Mb}$.

3) VGA Card (minimal $64 \mathrm{Mb}$, disarankan $128 \mathrm{Mb}$ atau lebih).

4) Harddisk minimal $80 \mathrm{~Gb}$ atau lebih dengan ruang kosong $1 \mathrm{~Gb}$.

5) Soundcard.

6) Mouse.

7) Keyboard.

8) Monitor dengan resolusi layar 1024 x600 piksel (disarankan 1280x720 piksel atau lebih) 


\subsection{Implementasi Kode Program}

Implementasi pembangunan setiap halaman fasilitas yang ada di aplikasi program pembelajaran tersebut tersaji dalam tabel 1. Kode program dibangun dalam bahasa program Adobe Flash CS 6 Profesional Edition.

Tabel 1. Kode program aplikasi program pembelajaran ipa materi sistem pernapasan manusia dan hewan untuk sdlb bagian $b$ tunarungu berbasis multimedia

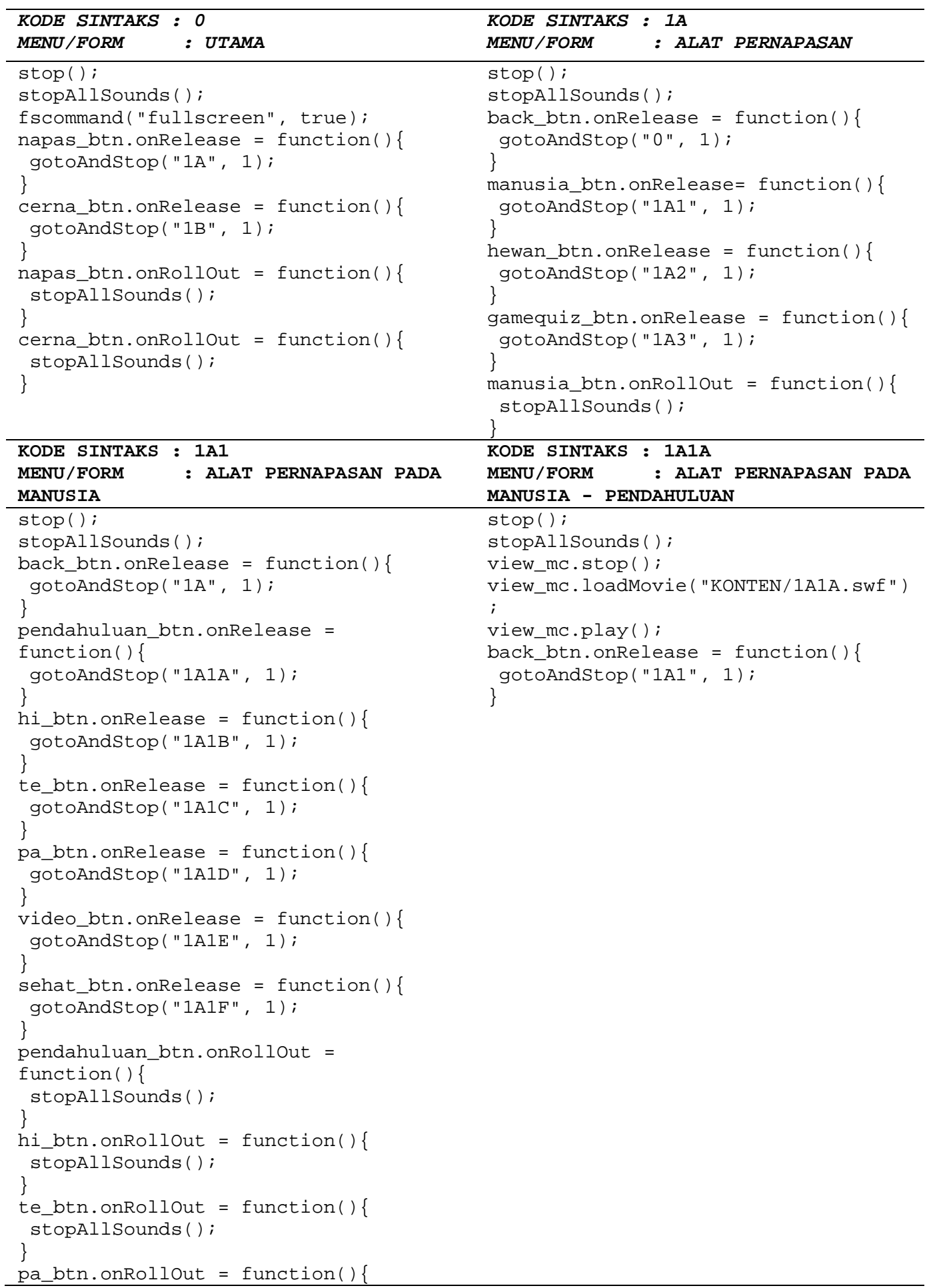




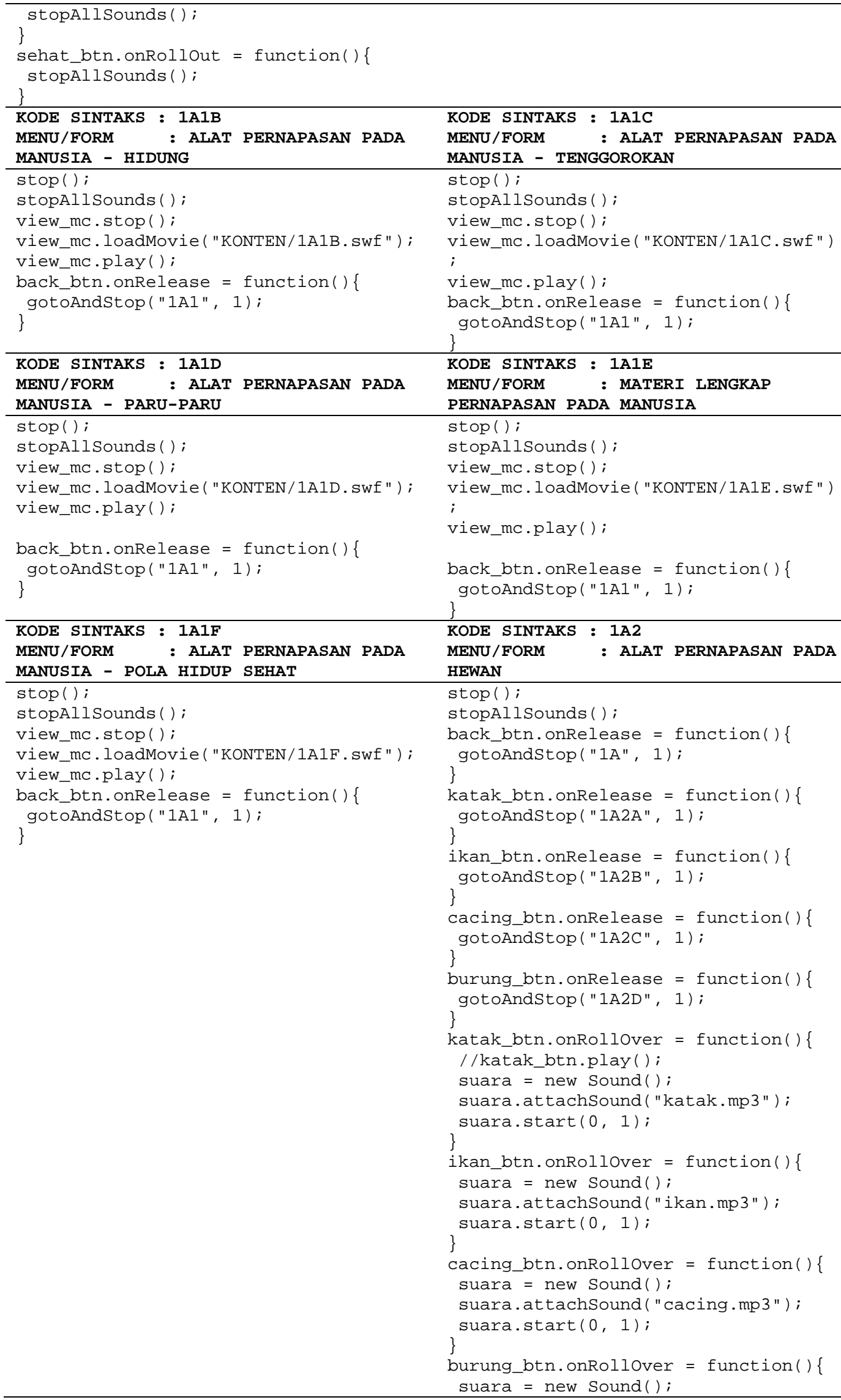




\begin{tabular}{|c|c|}
\hline & 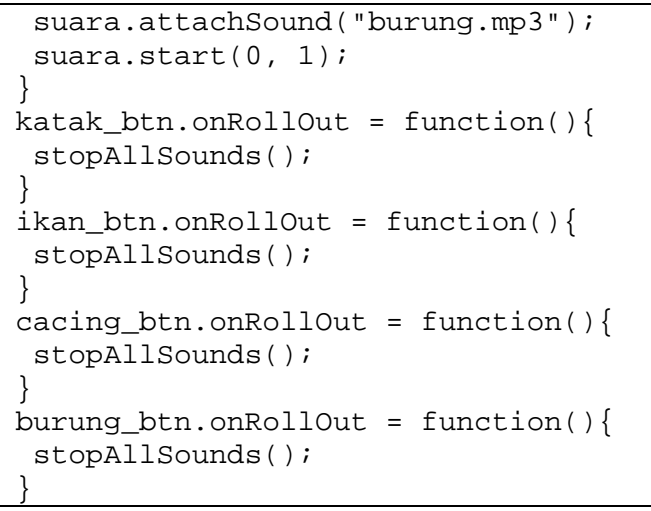 \\
\hline $\begin{array}{ll}\text { KODE SINTAKS } & : \text { 1A2A } \\
\text { MENU/FORM } & : \text { ALAT PERNAPASAN PADA } \\
\text { KATAK } & \\
\end{array}$ & $\begin{array}{l}\text { KODE SINTAKS : 1A2B } \\
\text { MENU/FORM } \\
\text { IKAN }\end{array}$ \\
\hline $\begin{array}{l}\text { stop( ); } \\
\text { stopAllSounds( ); } \\
\text { view_mc.stop ( ); } \\
\text { view_mc. loadMovie("KonTEN/1A2A.swf"); } \\
\text { view_mc.play( }) ; \\
\text { back_btn.onRelease = function( )\{ } \\
\text { gotoAndStop("1A2", } 1) ; \\
\text { \} }\end{array}$ & 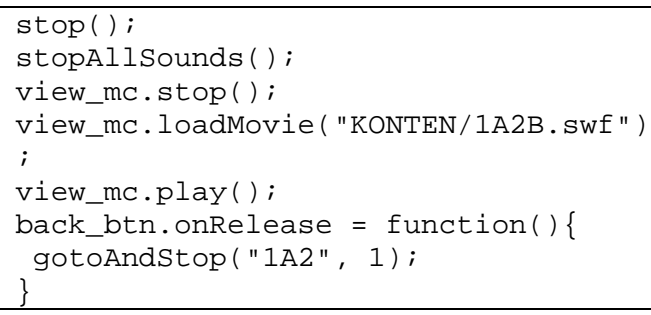 \\
\hline $\begin{array}{ll}\text { KODE SINTAKS } & : \text { 1A2C } \\
\text { MENU/FORM } & : \text { ALAT PERNAPASAN PADA } \\
\text { CACING } & \end{array}$ & $\begin{array}{l}\text { KODE SINTAKS }: \text { 1A2D } \\
\text { MENU/FORM } \\
\text { BURUNG }\end{array}$ \\
\hline 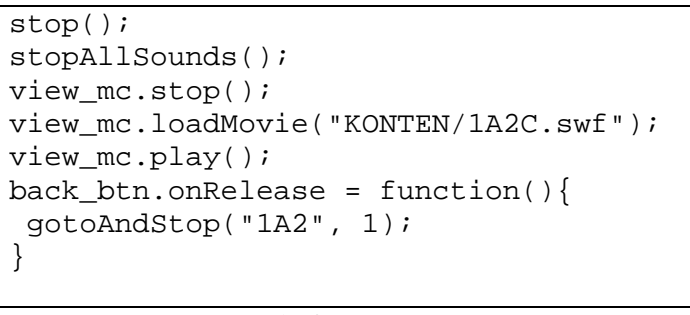 & 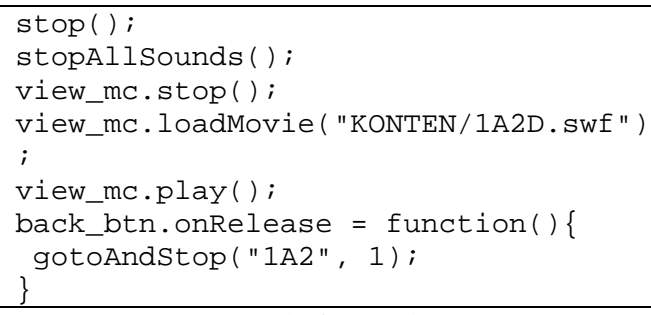 \\
\hline $\begin{array}{ll}\text { KODE SINTAKS } & : \text { 1A3 } \\
\text { MENU/FORM } & : \text { ALAT PERNAPASAN - } \\
\text { GAME \& QUIZ } & \end{array}$ & $\begin{array}{l}\text { KODE SINTAKS : 1A3GAME1 } \\
\text { MENU/FORM }: \text { ALAT PERNAPASAN - } \\
\text { GAME - PUZZLE }\end{array}$ \\
\hline  & 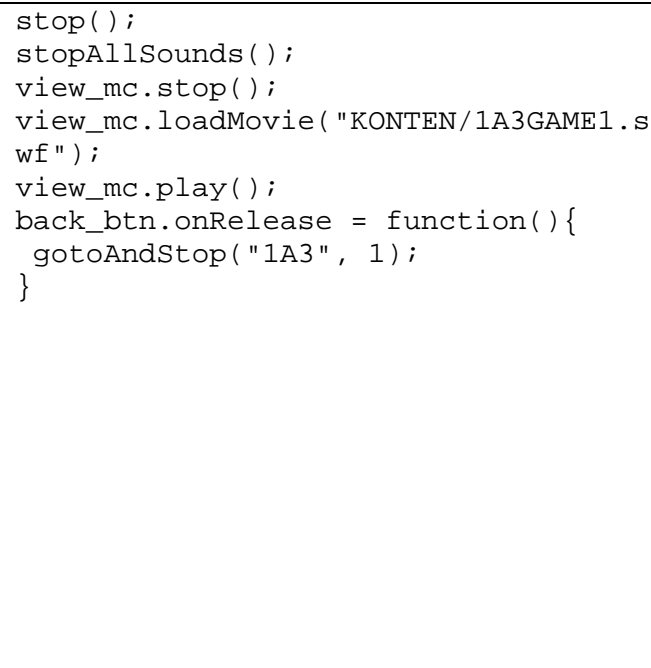 \\
\hline $\begin{array}{ll}\text { KODE SINTAKS } & : \text { 1A3GAME2 } \\
\text { MENU/FORM } & : \text { ALAT PERNAPASAN - GAME } \\
\end{array}$ & - TEKA-TEKI SILANG \\
\hline $\begin{array}{l}\text { stop }() ; \\
\text { stopAllsounds }() ; \\
\text { view_mc.stop(); } \\
\text { view_mc.loadMovie("KONTEN/1A3GAME2.sh }\end{array}$ & \\
\hline
\end{tabular}




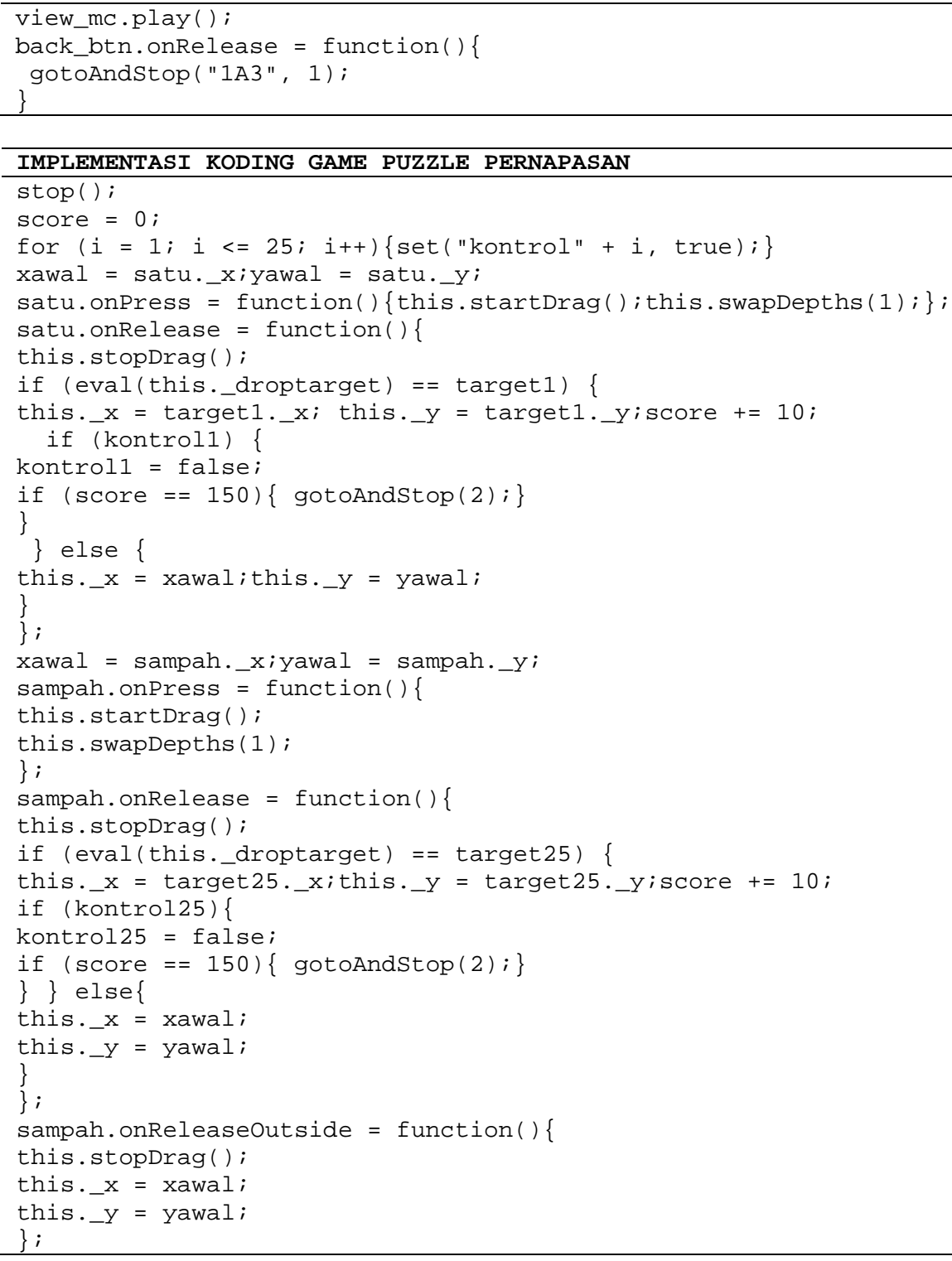




\subsection{Implementasi Antar Muka}

Implementasi antar muka diterapkan pada setiap bagian menu pada program aplikasi multimedia ini, tampilan antar muka dimulai dari pertama kali aplikasi dijalankan. Implementasi antar muka ini sesuai dengan hasil rancangan antar muka di penelitian sebelumnya [6]. Deskripsi dari tiap tampilan antar muka aplikasi terdapat pada tabel 2 .

Tabel 2. Tabel implementasi antar muka

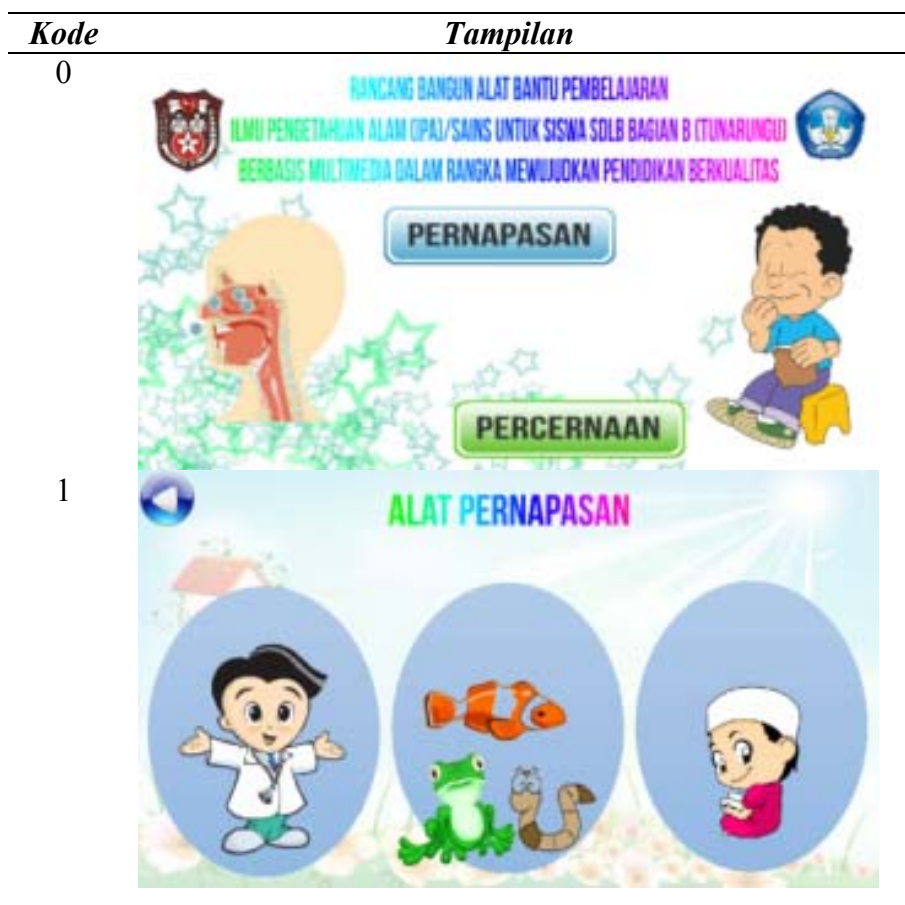
Keterangan

Tombol PERNAPASAN

menuju ke materi pernapasan

Tombol

\section{PERCERNAAN}

menuju ke materi pencernaan

Tombol

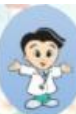
pernapasan manusia.

Tombol pernapasan hewan.

Tombol

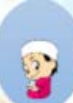

GAME \& QUIZ

Tombol : menuju ke menu sebelumnya

$1 \mathrm{~A}$



Tombol Pendafiufuan : menuju materi pendahuluan pernapasan manusia.

Tombol Mil-Hiding : menuju materi hidung.

Tombol TE-Tenggorokan : menuju materi tenggorokan.

Tombol -Paru-Paru : menuju materi paru-paru.

Tombol Pola Hiduy Sefiat : menuju materi pola hidup sehat.

Tombol : menuju materi lengkap

Tombol : menuju ke menu sebelumnya 


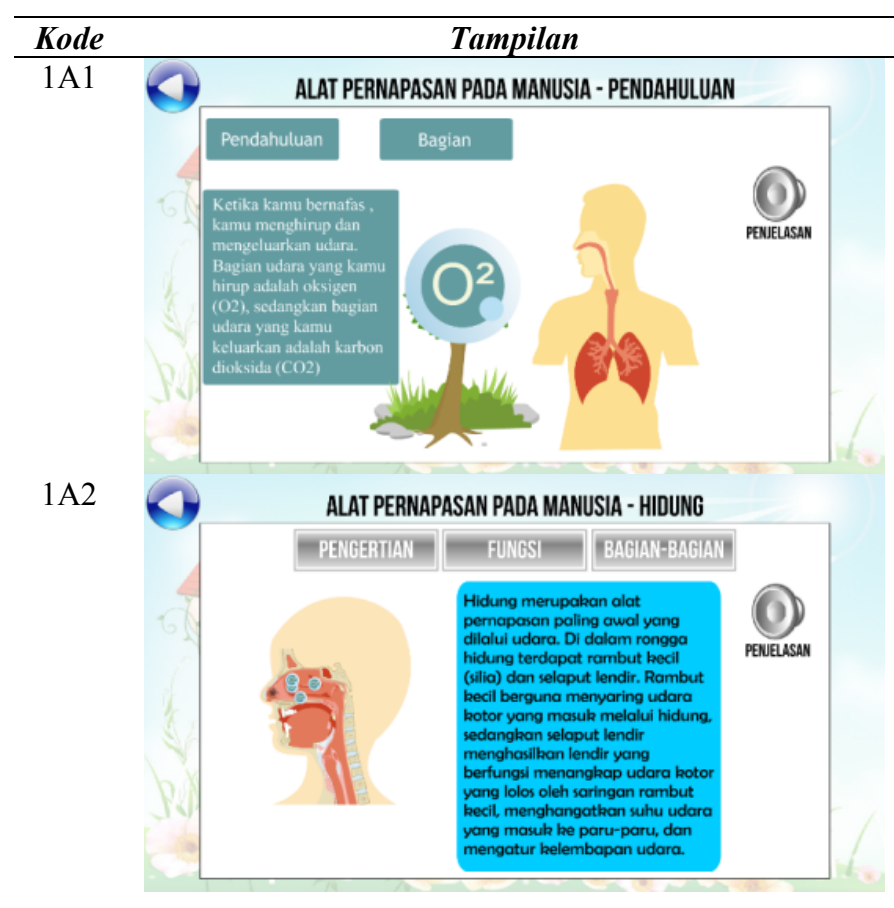

$1 \mathrm{~A} 3$

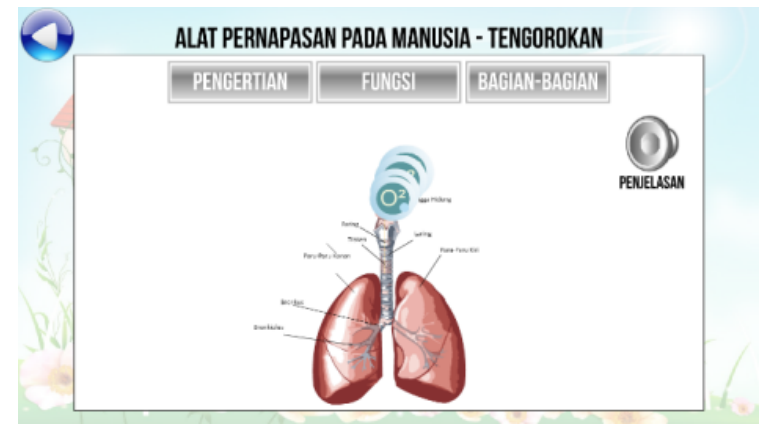

$1 \mathrm{~A} 4$

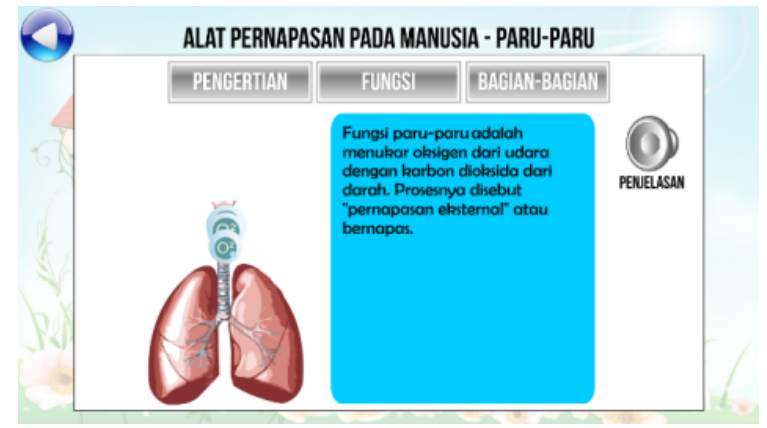

Keterangan

Tombol (2) : untuk memutar audio penjelasan.

Tombol Pendahuluan : untuk melihat materi pendahuluan

Tombol Bagian : untuk melihat materi bagian pernapasan

Tombol : menuju ke menu sebelumnya

Tombol (2) : untuk memutar audio penjelasan.

Tombol Pelloghtor : untuk melihat materi pengertian hidung

Tombol : Furks : untuk melihat materi fungsi hidung

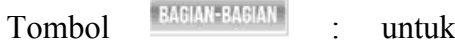
melihat materi bagian-bagian hidung

Tombol : menuju ke menu sebelumnya

Tombol (1) : untuk memutar audio penjelasan.

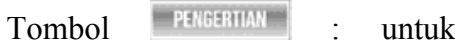
melihat materi pengertian tenggorokan

Tombol : untuk melihat materi fungsi tenggorokan

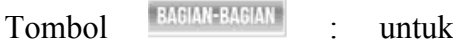
melihat materi bagian-bagian tenggorokan

Tombol : menuju ke menu sebelumnya

Tombol (2) : untuk memutar audio penjelasan.

Tombol Pellogritar : untuk melihat materi pengertian paruparu

Tombol Funcs : untuk melihat materi fungsi paru-paru

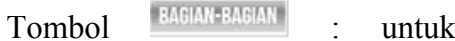
melihat materi bagian-bagian paru-paru

Tombol : menuju ke menu sebelumnya 


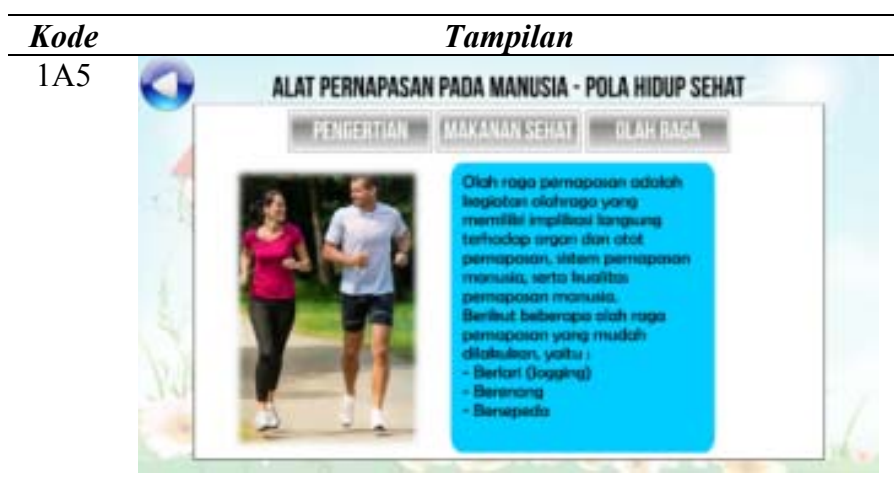

$1 \mathrm{~A} 6$

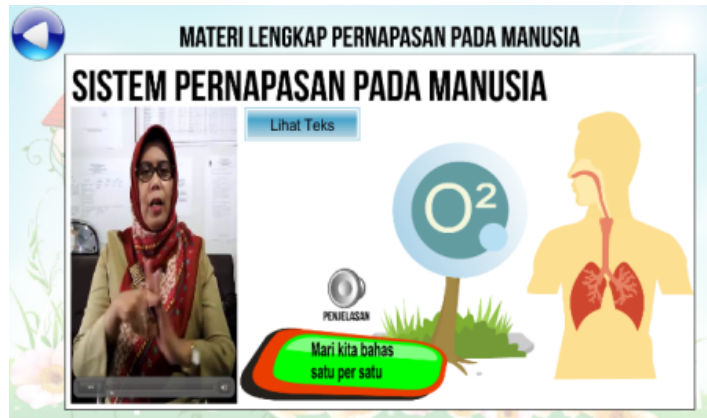

1B

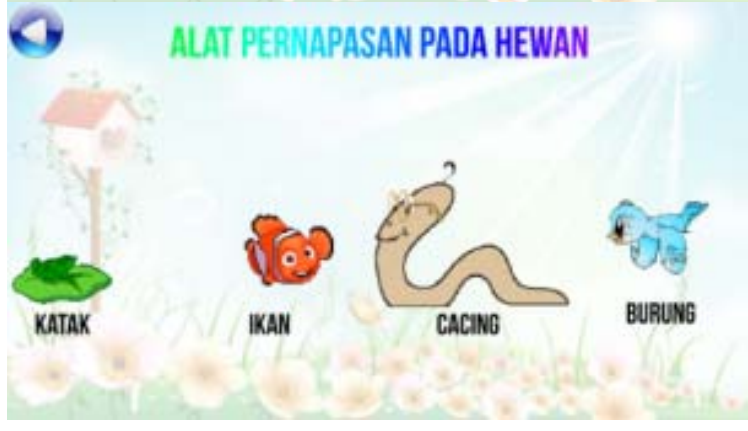

1B1

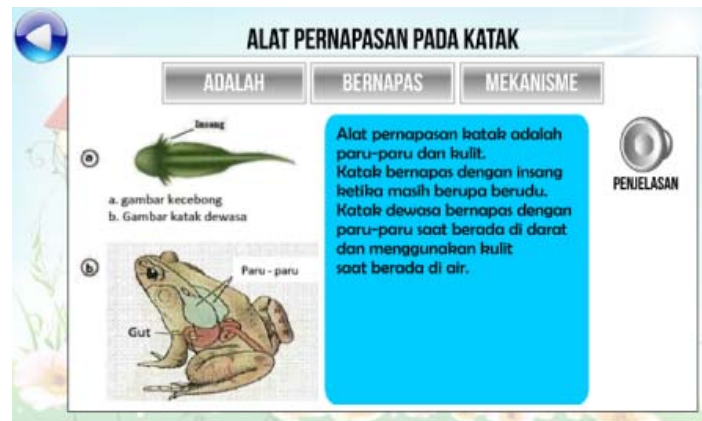

Keterangan

Tombol O) : untuk memutar audio penjelasan.

Tombol PErGERाMN : untuk melihat materi pengertian pola hidup sehat


melihat materi makanan sehat

Tombol OrAHRMA : untuk melihat materi olah raga

Tombol : menuju ke menu sebelumnya

Tombol (O) : untuk memutar audio penjelasan.

Tombol Lhat Teks : untuk melihat penjelasan teks

Tombol : menuju ke menu sebelumnya

Tombol катак : menuju materi pernapasan katak

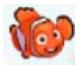

Tombol IkaN : menuju materi pernapasan ikan

Tombol : menuju materi pernapasan cacing

Tombol : menuju materi pernapasan burung

Tombol : menuju ke menu sebelumnya

Tombol (9) : untuk memutar audio penjelasan.

Tombol Andip : untuk melihat materi pengertian

Tombol BERVAPAS : untuk melihat materi cara bernapas

Tombol MakANisme : untuk melihat materi mekanisme pernapasan

Tombol : menuju ke menu sebelumnya 


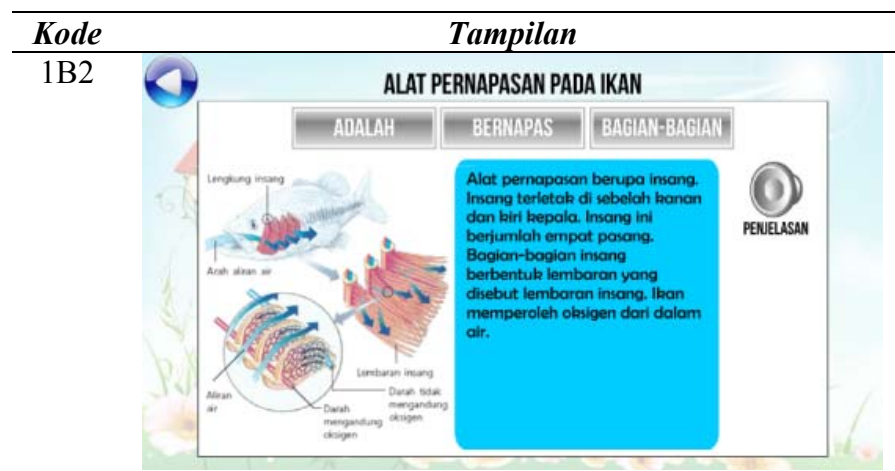

1B3

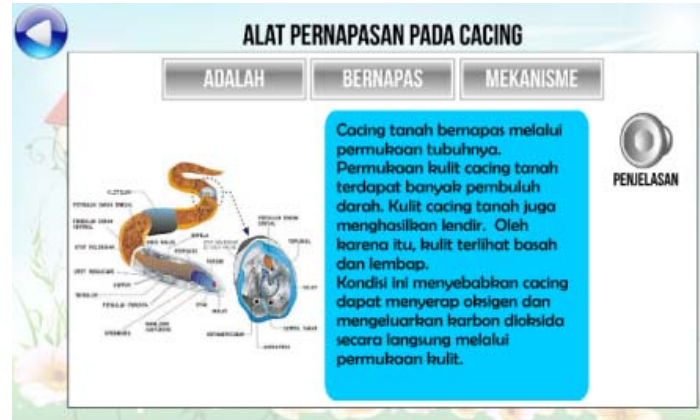

1B4

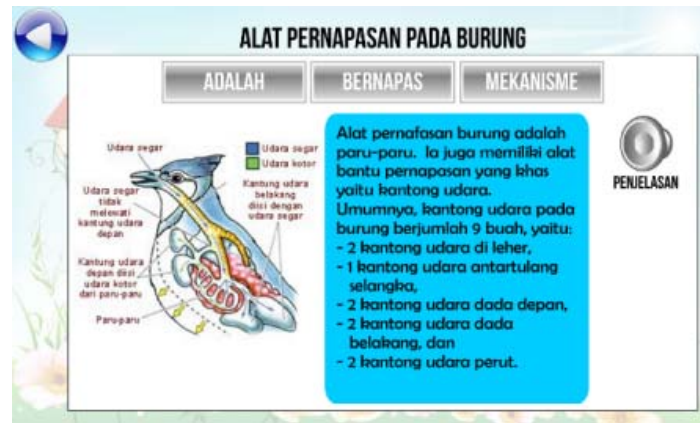

$1 \mathrm{C}$

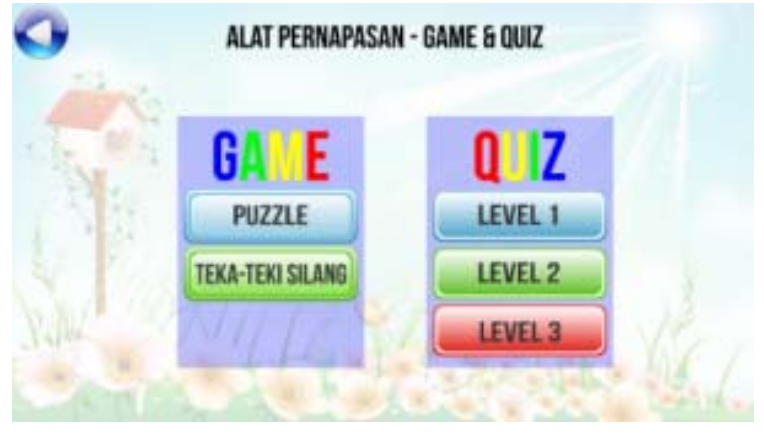

Keterangan

Tombol O) : untuk memutar audio penjelasan.

Tombol : untuk melihat materi pengertian

Tombol Bepripas : untuk melihat materi cara bernapas

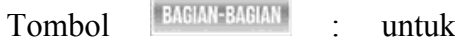
melihat materi bagian-bagian pernapasan

Tombol : menuju ke menu sebelumnya

Tombol Q1: : untuk memutar audio penjelasan.

Tombol : untuk melihat materi pengertian

Tombol BERHAR: : untuk melihat materi cara bernapas

Tombol mikanisme : untuk melihat materi mekanisme pernapasan

Tombol : menuju ke menu sebelumnya

Tombol Q : untuk memutar audio penjelasan.

Tombol : untuk melihat materi pengertian

Tombol Besripas : untuk melihat materi cara bernapas

Tombol Mgkdinsme : untuk melihat materi mekanisme pernapasan

Tombol : menuju ke menu sebelumnya

Tombol : menuju ke menu sebelumnya

\begin{tabular}{|c|c|}
\hline GAE & Game terdiri dari \\
\hline PUZZLE & \\
\hline TEKA-TEKI SILANG & Game puzzle dan \\
\hline 012 & Quiz terdiri dari 3 \\
\hline LEVEL 1 & leve \\
\hline LEVEL 2 & Dimulai dari level \\
\hline LEVEL 3 & $\begin{array}{l}\text { hingga level } \\
\text { (tersulit) }\end{array}$ \\
\hline
\end{tabular}




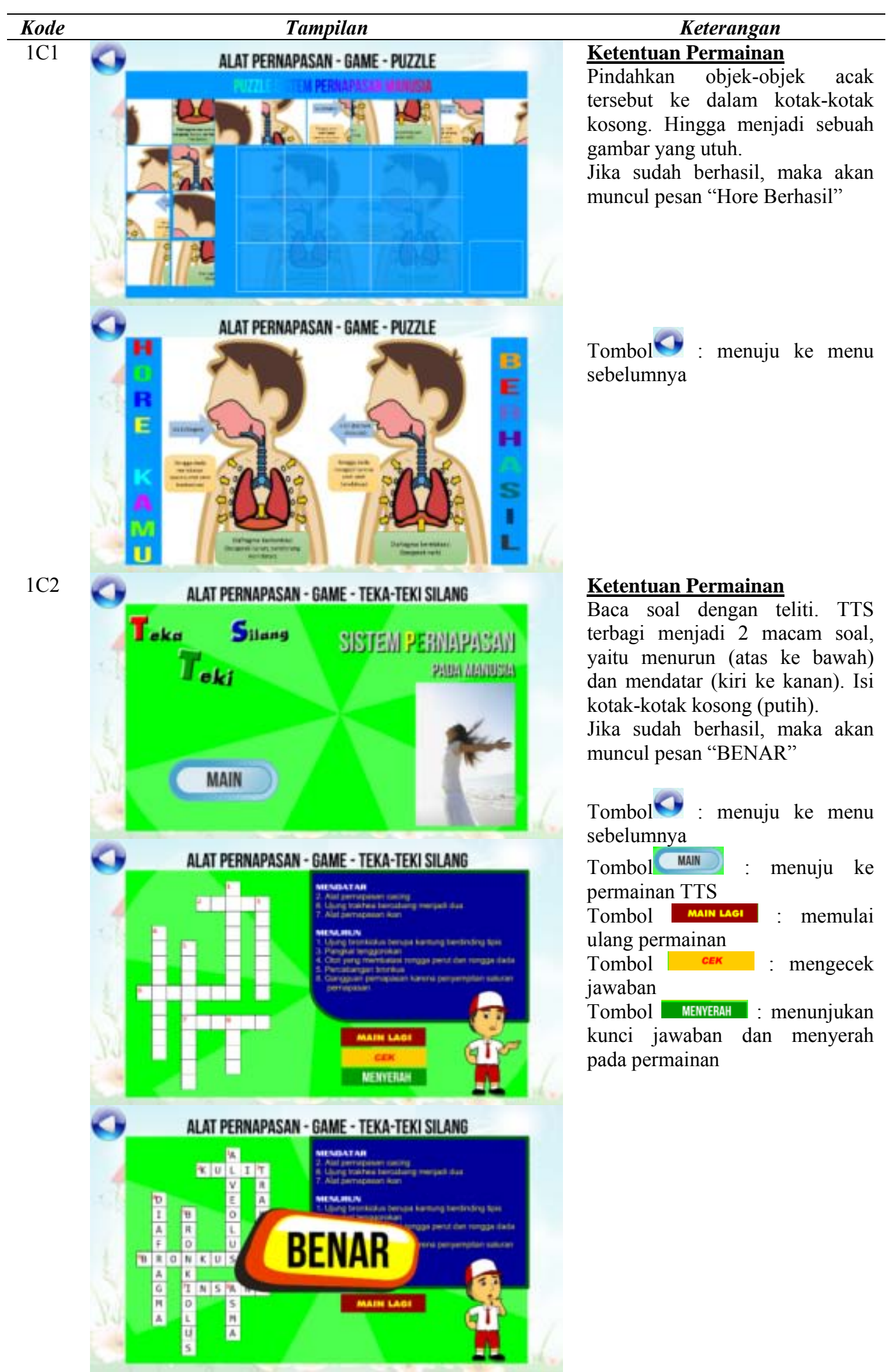



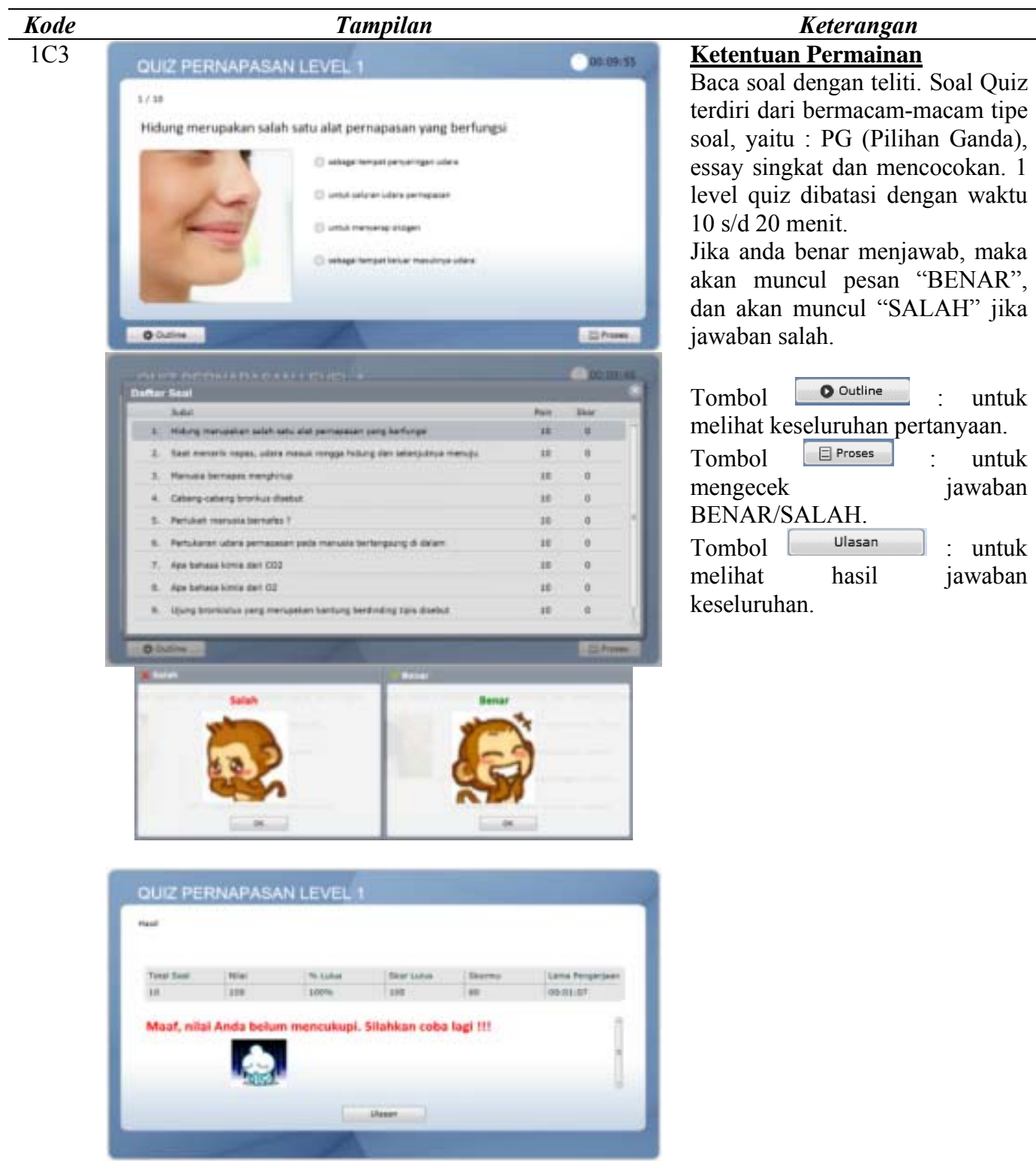

\section{KESIMPULAN}

Pengajaran IPA berbantuan komputer berbasis multimedia untuk siswa SDLB BAgian B tunarungu ini bukan menggantikan peran guru sebagai pendidik sebagai penyampai materi ajar, namun hanya sebagai media alternatif penyampaian materi ajar ke siswa dengan tujuan meningkatkan daya rangsang berpikirsiswa terhadap suatu materi ajar yang disampaikan dengan menggabungkan audio, visual dan animasi disertai bahasa isyarat.

\section{UCAPAN TERIMA KASIH}

Terima kasih penulis sampaikan kepada BP3IPTEK Provinsi Jawa Barat yang mendanai penelitian ini dalam Program Kegiatan Penigkatan Kualitas Penelitian Dosen PTS/N Dan Politeknik Untuk Pembangunan Jawa Barat Tahun 2016. 


\section{DAFTAR PUSTAKA}

[1] Suheri,

A. 2006 .

Animasi

Multimedia

Pembelajaran.

http://www.unsur.ac.id/images/articles/27_33_pak_agus.pdf, diakses 05Maret 2015.

[2] Rahmawati, E., 2013. Aplikasi Computer Aided Learning Untuk Mengurangi Resiko Learning Disorder Pada Anak Usia Pra Sekolah. Jurnal MONITOR, 2(2), pp.1-11.

[3] Effendi, Diana., 2014, Program Aplikasi Pembelajaran IPA MAteri Sistem Peredaran Darah Manusia untuk Siswa Kelas V SDLB Bagian B (Tuna Rungu) Berbasis Multimedia, Prosiding SNETE ke-4 Jurusan Teknik Elektro Universitas Unsyiah Banda Aceh, ISSN : 2088-9984, pp.5-10.

[4] Effendi, D., Hardiyana, B. and Gustiana, I., 2016. PERANCANGAN PROGRAM APLIKASI PEMBELAJARAN IPA MATERI SISTEM PERNAPASAN BERBASIS MULTIMEDIA UNTUK SISWA SDLB BAGIAN B TUNA RUNGU MENGGUNAKAN OBJECT ORIENTED APPROACH. Jurnal Simetris, 7(2), pp.605-618.

[5] Effendi, Diana., 2014. Learning Application Using Multimedia For $5^{\text {th }}$ Graders Elementary School Student about "Photosynthesis in Plants", Proceding The $1^{\text {st }}$ Sriwijaya University Learning and Education International Conference (SULE-IC), ISBN : 987-602-70378-0-9, pp.927-934.

[6] Prasetyo, Sigit., 2007, Pengembangan Pembelajaran Dengan Menggunakan Multimedia Interaktif Untuk Pembelajaran Yang Berkualitas. : UNNES.

[7] Leksono., Suroso Multi., Pengembangan Media Pembelajaran Berbantuan Komputer (Pbk) Untuk Sma Pada Materi Amfibi, http://www.sippendidikan.org/.../229_Suroso-Pengemb\%20Media.., diakses 05Maret 2015.

[8] Setyosari, Punaji. 2010, Metode Penelitian dan Pengembangan, Penerbit Kencana Prenada Media Group, Jakarta. 